\title{
INSTRUCTION AS INFLUENTIAL FACTORS TOWARD THE RATE OF CHILDREN IN LEARNING ENGLISH VOCABULARY
}

\author{
Rini Susilowati *)
}

\begin{abstract}
Abstrak
Kosakata merupakan salah satu hal yang penting untuk dikuasai dalam proses pembelajaran Bahasa Inggris, baik bagi orang dewasa maupun anak-anak. Artikel ini ditujukan untuk menggali lebih dalam tentang instruksi atau proses pengajaran itu sendiri dan faktor-faktor lainnya yang mempengaruhi tingkat kecepatan anakanak belajar kosakata bahasa Inggris. Di dalam artikel ini dipaparkan beberapa tekhnik yang efektif yang diaplikasikan di kelas untuk keefektifan proses pembelajaran kosakata seperti; demonstrasi dengan menggunakan gambar, objekobjek yang menyerupai benda aslinya, demonstrasi gerak tubuh, gambar dari buku, dan diagram. Selain itu, teknik yang dapat diaplikasikan di kelas, yaitu dengan memberi konteks makna dari bahasa target dengan definisinya dalam bahasa keseharian anak-anak. Hal lain yang dipaparkan di artikel ini adalah bagaimana instruksi atau proses pengajaran berpengaruh pada tingkat kecepatan anak-anak mempelajari kosakata. Selanjutnya dari instruksi atau proses pengajaran itu sendiri muncul beberapa faktor yang memengaruhi tingkat kecepatan anak-anak mempelajari kosakata, yaitu kemampuan guru mengemas proses pembelajaran, motivasi anak-anak itu sendiri, dan dukungan yang optimal, baik dari orangtua maupun guru.
\end{abstract}

Kata kunci: Instruksi atau proses pengajaran, tingkat kecepatan belajar, kosakata

\section{INTRODUCTION}

Children are unique and they are not the same from one another. Family background, race, and culture and other things will influence their personality traits, behaviour, attitude and achievement. They also have different ways in learning something including learning English vocabulary. Read (2000:1) state "vocabulary is the units of meaning from which larger structures such as sentences, paragraph and whole texts are formed". Foreign language learning should be supported by broad vocabulary. Some children learn new vocabulary faster than others. It is not surprising since the children tend to make progress differently depend how they learn at school, language exposure experienced by them at school or at home, and teacher's influence as well as parents' influence. Teacher's influence relates to instruction given in the classroom as well as how the teacher uses method, giving task and prepares nice activities. 
Instruction means teaching in general, or it may mean a particular kind of teaching (Edmonson,1999:71). Instruction is the process of teaching in the classroom. Whether instruction is one of the influential factors toward the children's rate in learning English vocabulary is the question. Edmonson (1999:72) states if we simply label bad teaching 'instruction', and then seek to show that instruction doesn't make much of a difference, then we are only showing that bad teaching doesn't help learning much. Instruction is not really significant to the rate of the children learning English vocabulary in the case that the instruction is not good. If the good instruction only the parameter to measure it, bad instruction becomes the negative factor toward the rate of the children in learning English vocabulary.

Someone who teaches using effective instruction will choose the suitable tasks for the children due to their need. Preparing the good task does not only concern to the material and the curriculum, it should be understandable to be done by the children eventhough the result of each pupil will not be the same. By doing the tasks in the classroom it is hoped that they can learn something new and it will contribute to their innate capacity in learning English vocabulary. Meanwhile, wise teacher should include demands and support in giving the tasks for the children. The tasks should be arranged based on the learners capability and need. Teacher should avoid the tasks which is time consuming meanwhile the goal of using the target language is not fulfilled. Cameron (2001:26) states "if the demands are too high, learners will find the tasks too difficult; they are likely to 'switch off' and not finish the task, or to finish it as well as they can, using what they know to complete the task but not using the language intended".

There is another factor influencing to the success of teacher's instruction which is classroom activity. Children are very active as long as they are healthy and they feel fun when they learn at school. There are children sitting quitely and they tend to really focus on what the teacher explain to them when they learn in the class. There are also children who tend to be interrupted easily by the noise and friends surround them, but they still can follow teachers' instruction. Meanwhile, there are also children who do not pay attention to teachers' instruction exposed to them since they are busy with their own activities such as playing and drawing. Considering different condition faced by the teachers in the classroom, they should create such fun and interesting activities to grab children attention in the classroom. Concerning to the importance of those factors toward children's rate in learning English vocabulary, the next part of 
this article will elaborate further some details of those things.

\section{DISCUSSION}

Children learnt vocabulary long before they went to school learning through formal instruction. Starting from the early age at infant stage until the school age they have recorded and learnt a lot of vocabulary. Children memorize everything easily as long as they often hear the words exposed to them or they often see or read the words exposed to them. Storing new vocabulary especially English vocabulary will be better if it started earlier since children's innate capacity are on their golden age. Cameron (2001:72) states"building up a useful vocabulary is central to the learning of foreign language at primary level”.

At the beginning English vocabulary learning children at primary level are introduced to sme basic things such knowing daily objects surround them, greetings, introducing, alphabet and numbers. They tend to do bottom-up process since they learn English vocabulary from the smallest unit of the language which is word. This called vocabulary development. Cameron (2001:73) states "vocabulary development is about learing words, but it is about much more than that. Vocabulary development is also about learning more about those words, and about learning formulaic phrases or chunks, finding words inside them, and learning even more about those words. In the attempt to support children vocabulary development, teachers should concern to some aspects in their instruction.

First, the techniques used to introduce the types of words that the children learn. Nation (1990:51) in Cameron (2001:85) determine some basic techniques by which the teachers can use to explain the meaning of new words which are by demonstration or pictures and by verbal explanation. Some examples of the first technique are using an object, using a cut-out figure, using gesture, performing an action, photographs, drawings or diagrams on the board, and pictures from books. Children can remember daily objects, surround them easily by the concrete vocabulary that they see or touch. In this situation teachers can bring various imitative daily objects. Cameron (2001:81) states"five years old learning a foreign learning need a very concrete vocabulary that connects with objects they can handle or see, whereas older learners can cope with the words and topics that are more abstract and remote from their immediate experience". Showing the real objects, realia and pictures will be helpful in this case. Nation (2001:85) states"real objects, pictures, etc. are often seen as the most valid way of communicating the meaning of a word.

Some examples of the second technique are analytical definition, putting 
the new word in a defining context, and translating into another language. Analytical definition does not suit to younger children whose vocabulary is limited. Younger children will face obstacles anytime they learn difficult vocabularies and the teacher guide them to understand it by giving definition of the words. Children at this age are likely to collect a lot of new words but they have not had capability to link those words into meaningful sentences. Cameron (2001:81) states "the very young learners will learn words as collections, older children are much more able to make connections between the words they learn and to use the paradigmatic organisation of words and concepts as a help in vocabulary learning”. Meanwhile, putting the new word in a defining context is also suitable for older children having advanced vocabulary development. Putting the new word in a defining context involves logical thinking to relate between the meaning and the context in which the word used. Therefore, children's critical thinking is needed when this technique used by the teachers instead of knowing only one single word meaning. Related to the two techniques exposed previosly teachers should be careful to apply the techniques of their instruction. Teachers should consider the age and children learning level in order to apply the suitable technique for the sake of the children. The last is Translating into another language.
Translating sometime done by the teachers whose students are nonnative students.

$$
\text { Cameron (2001:199) states “in }
$$

practice, research and anecdotal evidence suggests that most teachers who share their pupil's mother tongue, use a mixture of the foreign language and the mother tongue. In addition, teachers themselves are not really fluent in using English since they are also nonnative teachers. According to Cameron (2001:200), one important reason may be that teachers do not feel sufficiently confident or competent to use the foreign language for the full range of functions that are created by activities and tasks in lessons. Teachers think that by giving definition in students' first language can diminish the obstacles in understanding the meaning. As the consequence students will depend their teachers' help. According to Cameron (2001:203), the choice of first or foreign language for particular function can convey to pupils a sense of how much their teachers 'is on their side' or, alternatively, wishes to distance him or herself from the pupils' concerns. If the teacher uses the first language in the foreign language classroom, she or he may thereby create a feeling of being aligned with the pupils. Meanwhile, learning a foreign language not only learn a collection of words. Learning a foreign language need practice, recycling process and repetition. Children need to see the words and to hear it many time so they keep 
it on their memory for long time. Cameron (2001:81) states "vocabulary development is not just learning more words but is also importantly about expanding and deepening word knowledge. Children need to meet words again and again, in new contexts that help increase what they know about words". Teachers should not always translate difficult words into another language which may diminish children's motivation to think. Some pictures, imitative objects, and other media are the other options to overcome this problem. Therefore, choosing suitable technique in the classroom will influence children learning progress.

In addition to the techniques used in teachers' instruction in vocabulary learning, Takac (2008:20) state that there are five techniques can be applied in the classroom which are; connecting an L2 item with its equivalent in L1, defining the meaning, presentation through context, directly connecting the meaning to real objects or phenomena, active involvement of learners in presentation. Connecting an L2 item with its equivalent in $L 1$ is often used when teachers want to measure children's comprehension development. Usually teachers will give the translation of L2 words into L1 if the children hardly understand the meaning of the words. Furthermore, this case often found in nonnative class where the children are not habitual to use English as their daily language. Connecting an L2 item with its equivalent in $\mathrm{Ll}$ is the commonest technique often by nonnative teachers. Usually in their instruction teachers often give translation in L1 if the children hardly understand the meaning of the words.

Defining the meaning can take many forms: synonym, antonym, analytic definition, taxonomic definition, giving examples, giving the superordinate terms, describing the function, grammatical definition, definition by connection, definition by classification, full definition (Takac, 2008:20). For example, teachers can give instruction related to meaning of the word 'see' by giving its synonym which is 'look'. When the teachers explain about the meaning of 'small', they can refer to the opposite meaning which is 'big' while they are pointing something which is big. The next technique is presentation through context. In giving instruction through this technique teachers can relate the context of certain situation in which the word is used using one single sentence or some sentences and the children guess the lexical meaning. For example, in their instruction teachers want to explain the meaning of 'eat'. They can explain that eating means 'you take food in your mouth when you are hungry'. Meanwhile, directly connecting the meaning to real objects or phenomena can be done using some real objects such as puppet and realia. For example, when teachers explain about 'proffesion', they can show the puppet 
wears doctor uniform with the stetoscop. Meanwhile, active involvement of learners in presentation encourages older children to be more active to develop their vocabulary by doing some activities in front of the class. For example, in their instruction teachers can ask older children to supply some words on some pictures showed on the board. They put some pictures of daily objects at home without the name of its picture and the children give the appropriate name based on the pictures.

Second, three general processes which cause the words being remembered and stored in children memory. Nation (2001:6) state that there are three general processes which stimulate the children having words kept for a long time on their memory; which are noticing, retrieval, and creative and generative use. Teachers should concern to these three proceses so their teaching would be effective. Noticing is the process in which teachers encourage the children to pay attention to all new words introduced to them. Nation (2001:6) states "the first process encouraging learning is noticing, that is giving attention to an item. This means that learners need to notice the word, and be aware of it as a useful language item".

Noticing should be done with the goal to atrract children's attention while they are learning. For example, older children look for word meaning in dictionary, younger children see the words written by teachers on the board and understand the meaning through teacher explanation. According to Nation (2001:65), there are some ways to make noticing can occur in the classroom which are; children notice the new words while reading or listening, teacher highlight a word while writing it on the board, children discuss word meaning to their friends or teacher, teacher explain the words to the children by giving definiton, synonym or first language translation.

Meanwhile, retrieval is learning the new words frequently. The more children see and hear the new words exposed to them, the more new words put on their memory. Nation (2001:67) states "a word may be noticed and its meaning comprehended in the textual input to the task, through teacher explanation and dictionary use. If that word is subsequently retrieved during the task then the memory of that word will be strengthened". For example, in their instruction teachers can repeat the same material through different activity and task. In certain occasion teachers can ask the children to complete the blank space of the missing alphabet on some words to convey meaning of the words. In other occasion, teacher can ask the children draw the line from the words learnt before to the correct picture which represent the words.

The last is creactive or generative use. Using this technique in their instruction teachers can encourage older children to be 
more aware that one word could be used in different occasion and context and it triggers different meaning sometimes. Nation (2001:68) states "generative processing occurs when previously met words are subsequently met or used in ways that differ from the previous meeting with the word. For example, teachers can explain that sentence 'mother makes cake for us' contains verb 'make' which similar to the word 'cook'. In other occasion, in their instruction teachers can explain that the word 'make' can be used to refer to an activity to create something instead of cook or make something in the kitchen such as 'I make toy car'. This technique is suitable for older children whose analytical thinking and vocabulary development have been well improved.

Instruction as stated previously is teaching process in the classroom. Instruction influencing the rate of children learning. There are some factors which influence the rate of the children in learning English. First, the factor behind the instruction itself which is the teacher. It think we should consider teacher as one of the important factor. Instruction means nothing if the teacher is not good. It means instruction is only instruction. Meanwhile, to be a good teacher who will give good instruction, a teacher should possess some essentials requirements. The first requirement is the teacher should know who children are. The teacher should know whether the children are the slow learners or fast learners so the teacher can treat the children appropriately by using the appropriate method, teaching strategy, and delivery method. The second requirement is the teacher should know how the children learn. Children like to learn by using interesting media, learning through games, direct activity and demonstration, having clear description about something (description about color or things by using pictures) and learning through exposure (direct contact and interaction with others). According to Suyanto (2010:47) generally children learn words faster if they are supported by demonstration media such as pictures and real objects. The reason for using demonstration media to depict the meaning of the word through seeing the pictures and the real objects. The third requirement is the teacher should know how the children learn a language. Children tend to imitate adults when they learn a language because they listen first to the target language which is exposed to them. After that they can produce what they listen before. Furthermore, they need to be engaged in direct interaction in which they use the target language so that they will get accustomed to use the target language. Young learners acquire a language from direct contact with language in use, including observing and participating in literacy practices; watching 
how people read and write for functional real purposes; and participating in literacy events. The fourth requirement is the teacher should know how children learn English as foreign language. Children tend to think that learning a new language is not so easy if they do not know the language. They need to learn it comfortably without enxiety and confusion. That's why the teacher should use the language comfortably also in order to make it as the target language in the classroom. From the explanation above it can be concluded that the factor is not the instruction, but the teacher. How can the teacher create good instruction by having some essentials requirements.

The second essential factor which influences to the rate of the children in learning English is motivation. As stated by Dornyei (2001:5) that the success of mastering a foreign / second language is determined by enthusiasm, commitment, and learners' persistent. Furthermore, Dornyei (2001:5) states, "without sufficient motivation, however, even the brightest learners are unlikely to persist long enough to attain any really useful language". Motivation is one of influential factor in language learning. Based on Dornyei's statement before I think motivation is correlated highly to the educational achievement. In learning English motivation really influences to how well the children will learn the language. It is not enough just count on the instruction. Motivation is needed in order to increase the children's will to learn. If the students do not have high motivation how can they enjoy the learning. In this case, teacher and parents as the external factor outside the children' self can encourage them having sufficient even high motivation. If the children come to the school and sitting in the classroom by bringing motivation, the teacher will teach them easily because they are already having interest to learn the target language. Automatically it will affect the rate of the children in learning the target language.

The third factor influencing the rate of children learning is optimal support. The optimal support from the parents is really influential to the children's interest and motivation. Parents should be able to form the view in children's mind that learning a language especially English is interesting and enjoyable. Parents can start to introduce a new language in this case English from the early age. They can give the children some interesting books for the children to read which is written in English such as story books, books about kinds of animals, fruits, things at home or other interesting books. This can be such a trigger to arise the children's interest. If the children have already been familiar with the language, the parents can send their children to schools to learn further about English if they have been 
three or four years old. As stated by Edmonson (1985) that we might want theory of optimal support. This would seek to say how the environment in general can best help. Moreover, I think the support from the teacher is also important to increase the children's interest and motivation. The attitude of the teacher toward the language and how the teacher can convince and create such an enjoyable atmosphere in learning the language can increase the children's motivation in learning the language. To conclude this part, the instruction will not be really influential to the rate of the children in learning English if the teacher only teach without consider the children's progress.

The fourth factor influencing to the rate of children learning is cognition. Some linguists believe that some children learn faster than other children because some children have greater cognitive ability. It causes them to have greater innate capacity in language learning. In other word it can be said that it is the internal factor from the children themselves. Cognition is related to intelectual processing. It means the way the children capture the material from the teacher, the way they comprehend the material will influence to the rate of their learning. Basically, I think all children were born with the same cognitive capability, in the case they do not have mental disturbance, but later on the progress of it depends on how the parents can maximize it by giving such a positive stimulus to optimize its work. Nevertheless, we cannot doubt that cognition will affect significantly to the rate of children in learning a language. I think the result of the learning from good instructed class with children who have good cognition will be better.

The last influential factor toward the rate of the children in learning English is the children's personality. They are not the same. Some are timid and introvert children, but some are really extrovert and they can learn everything easily by interacting with their teachers and friends. Introvert and anxious children will make slower progress in oral skill because they seldom take chance to speak. They are afraid in making mistakes. On the other hand, extrovert children will not take the mistakes seriously because they do not think it is a burden for them. They think it as a usual thing in learning process so they will learn more comfortably. In this case, I think the teacher should be aware of the children differences so the teacher can treat them differently and give more intensive attention and giving more support and encouragement for timid and introvert children.

\section{CONCLUSION}

Considering that there are some influential factors which influence the rate of the children in learning English, the teacher should not only focus on the intsruction. 
Instruction without interesting delivery method will make the children bored and it can diminish their interest and motivation to learn. Meanwhile, instruction without knowing the children's need in support toward them will let the introvert and anxious children learn slowly all the time. Furthermore, in the time when the teacher giving the instruction to the children, the teacher can do something to optimize the children's cognition by making them to be active in speaking, using some interesting pictures and media to increase their understanding toward the material. To sum up, instruction is only one of the external factors which influences to the rate of children in learning English. The teacher should strongly take notice to other factors which are also important.

\section{REFERENCE}

Cameron, L. 2001. Teaching Languages to Young Learners. Cambridge: Cambridge University Press.

Dornyei, Z. 2001. Motivational Strategies in the Language Classroom. Cambridge: Cambridge University Press.

Edmonson, W. 1999. Twelve Lectures on Second Language Acquisition. Gunter Narr Verlag Tubingen.

Nation, I.S.P. 2001. Learning Vocabulary in Another Language. Cambridge: Cambridge University Press.

Read, J. 2000. Assessing Vocabulary. Cambridge: Cambridge University Press.

Suyanto, K.K.E. 2010. English for Young Learners. Jakarta: Bumi Aksara.

Takac, V.P. 2008. Vocabulary Learning Srategies and Foreign Language Acquisition. Clevedon: Multilingual Matters LTD. 